\title{
Obong Victor Attah International Airport Contributions to Tourism: A Case Study of Three (3) Communities in Uyo Local Government of Akwa Ibom State, Nigeria
}

\section{Ihuoma $\mathrm{BA}^{1}$ and Raimi $\mathrm{MO}^{2 *}$}

${ }^{1}$ Department of Geography and Natural Resources Management, University of Uyo, Nigeria

${ }^{2}$ Department of Community Medicine, Niger Delta University, Nigeria

*Corresponding author: Raimi Morufu Olalekan, Department of Community Medicine, Environmental Health Unit, Faculty of Clinical Sciences, Niger Delta University, Wilberforce Island, Bayelsa State, Nigeria, Tel: +2347038053786; Email: ola07038053786@gmail.com

\section{Abstract}

Background: Tourism has been known as one way of addressing the challenges of economic diversification from the traditional agricultural or oil mono-economy in this $21^{\text {st }}$ century. Interestingly, air transportation is an important feature of economic development. It represents one of the yardsticks for assessing development. Many studies show that airport infrastructure is positively linked to socio-economic growth and development specifically in terms of generating employment, creating wealth, generating income, stimulating tourism and improving standard of living. This study aimed to measure the contributions of the Obong Victor Attah International Airport to the social and economic life of host communities of Uruan, Okobo and Nsit-Atai. LGA's in Akwa-Ibom State. Tourism is the major parameters used in measuring these contributions.

Materials and Methods: A buffer was used to demarcate the study into zones and a systematic sampling technique was employed in selecting the households to be sampled. The sample size composed of 400 respondents and this was determined from the population of the host communities using the Taro Yamane formula. Data needed for this study was obtained from questionnaires administered to the 400 respondents. Secondary data was collected from Obong Victor Attah International Airport Development Company. Data collected were analysed using; percentages, charts, maps and simple linear regression statistical tools. The hypothesis formulated was tested using simple linear regression analysis, the null hypothesis which stated that airport does not significantly impact tourism.

Results: Results from the analysis revealed that the airport has an influence on tourism which is due to the influx of visitors and the increased number of tourism related business majorly production of souvenirs and souvenir related 


\section{Journal of Ecology \& Natural Resources}

businesses. From this result it is here inferred that Obong Victor Attah International Airport is not the major determinant of tourism in the study area of the host communities.

Conclusion: It was recommended that the Government should create more employment opportunities for the host communities to improve their socio-economic well-being. Also, there is need for widespread campaigns in order to raise awareness among the host community members about the importance of airport to tourism.

Keywords: Tourism; Economic Development Sustainable Development Goals (SDGs); Contribution; Air Transportation; Uyo Local Government; Nigeria

\section{Introduction}

Tourism is increasingly being promoted as an important source of economic growth especially in developing countries. While there are many elements that contribute to tourism growth, without an efficient air transport system, it is almost impossible for a number of landlocked and geographically isolated developing nations to expand and sustain domestic and international tourism. Transport in general is important when there is need to explain tourism growth. Air transport occupies a central position in the long-haul tourism. Air access is a necessary precondition for international tourism, and in many cases for domestic tourism for many developing nations [1]. Various studies including Costa (2014) [2]; Basnet (2015) supports this assertion [3].

However, tourism industry is known to be the largest industry in the world, with receipts from international tourism expenditure totalling US $\$ 474$ billion in 2004 and it is estimated by the World Tourism Organization to continue to grow up to the year 2020. Tourism represents a rapidly rising proportion of world trade. In 1999, tourism represented over $40 \%$ of exports of services and about $8 \%$ of the entire global exports of goods and services exceeding trade in items like food, textiles, and chemicals $[4,5]$. Furthermore, the pre-eminence of the industry in trade is quite widespread; according to the World Tourism Organization (WTO, 2001) [6], it ranks among the top five export categories for $83 \%$ of countries and is the dominant source of foreign exchange earnings for not less than $38 \%$ of them. Interestingly, Third World countries are blessed with numerous tourist resorts and attractions, the foregoing benefits have largely eluded the region due to the poor state of the industry and ensuing low patronage, and inadequate government attention. Quite recently, governments of developing countries began to commit huge financial resources to the sector; particularly the hospitality and nature reserve (parks) sectors, because of the realization that the industry is a veritable tool for poverty alleviation and attainment of the sustainable development goals (SDGs) [5].

Costa VN [2] in a study on Regional Portuguese Airports, Local economy and Tourism development gave results which showed that approximately 869,000 tourists arrived in the north through Oporto Airports. The area recorded 2.4 million tourists in 2010 and 3 million in 2012. The performance impact of these tourists was quantified based on their length of stay and average daily expenditure throughout the years. Analysis reveal that the total expenditure of non- resident tourist grew by $559 \%$ which resulted in an increased of turn- over in the tourism sector. The annual proportion of tourist was obtained from average quarterly data from the institute of planning development. An average stay of these tourists in 2004 was assumed to be equivalent to 2010 and an average daily spending was updated at an upgrade rate of $6 \%$. Basnet S [3] studied air transportation impact upon the tourism industry of Nepal; Tribliuvan International Airport was used as a case study. The objective of the study was to find the relationship between air transportation system and tourism industry of Nepal. Data used for this study was collected from many sources such as Ministry of Tourism and civil authority, world travel and tourism council and aviation safety networks. Statistics obtained from the research showed that about 29 airlines flew about 3.14 million through the airport. It was increased by 7.35 percent from the year 2012. In total the foreign and domestic carriers combined carried about 4.68 million passengers in 2013. TIA saw 92,695 take-offs and landings in 2013, making it an average 254 flights per day. This could surmise to concluding that within the period studied, there were developments and advancements in the area of tourism within the studied region.

In assessing the impacts of civil airport layout on Yunnan local tourism industry Jian, et al. (2016) [7] used a co-relationship analysis to ascertain the relationship 
between aviation performance, tourism revenue and urbanization rate. Co-relation, co-analysis with SPSS 19.0 was used for the cities around the airports. This helped in knowing the extent of urbanization and the nearest airport passenger throughout. Multivariate linear regression analysis model based on the growth of tourism revenue and resources and passenger traffic volume was used for the study. Urbanization rate data, social and economic data was collected mainly from the provincial, statistical yearbook, tourism development data which includes; annual tourist, number of domestic and foreign tourist, annual tourism income mainly from Yunnan tourism report, National scenic area and the world cultural heritage. These data was mainly collected from the annals of the Yunnan airport group. Their results showed that there is high degree of positive co-relation between tourism and aviation. Statistics show that Yunnan tourism industry has achieved a rapid development driven by the aviation industry from 20052013 , the total revenue increased from Y42,000,000,000 to $\mathrm{Y} 211,124,000$ an average increase of $50.3 \%$, the total number of tourists increased from $70,110,000,000$ to $244,000,000$ an average annual increase of $31 \%$. Results also show that tourism revenue accounted for more than $10 \%$ of the total GDP which still increases by the year. Tourism review (2017) showed that $40 \%$ of passengers would not have visited the area in the absence of air service connections. It was also estimated that expenditure by these visitors sustained 3,889 jobs. These estimates and results were gotten from an inbound survey of passengers at Cork Airport in Ireland. The following objectives were the targets of this paper; to evaluate the impact of the Airport on tourism.

\section{Research Questions}

How has the airport influenced tourism of the host communities?

\section{Hypothesis}

The following null hypothesis would be tested;

$\mathbf{H}_{\mathbf{0}}=$ Obong Victor Attah International Airport does not significantly influence tourism.

\section{Materials and Methods}

\section{Study Area: Location}

The Obong Victor Attah International Airport is an Airport in Akwa Ibom State, Nigeria, this Airport is hosted by three (3) local governments which constitute the study area. They are Okobo, Nsit Atai, and Uruan local governments. The area is located within the coordinates $8.00 \mathrm{E}-8.50 \mathrm{E}$ and $4.500 \mathrm{~N}$ and $4.550 \mathrm{~N}$ (Figure 1).

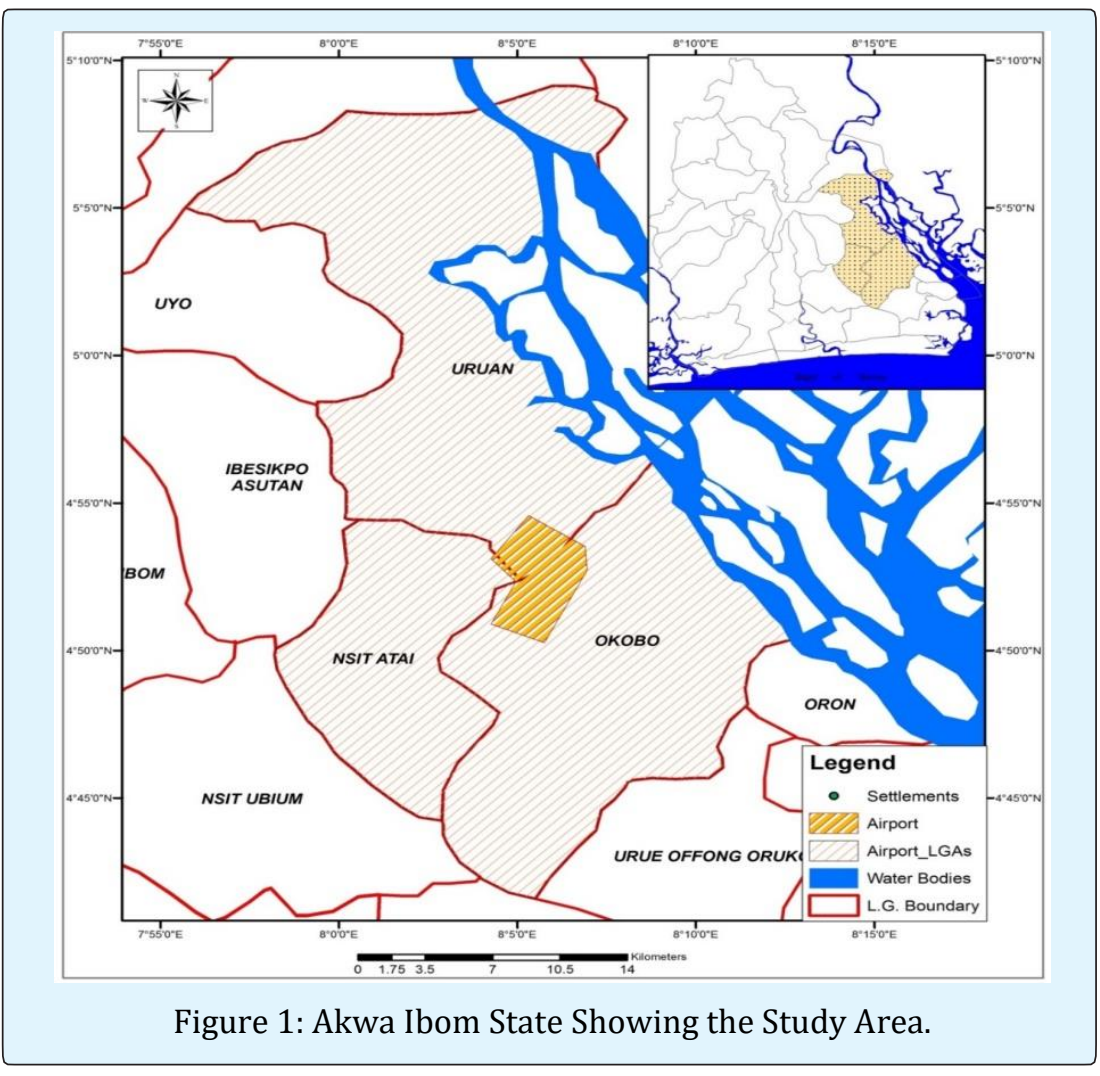


People and Population: The people are mainly Ibibio's, with Ibibio language as the major spoken language. Ibibio constitute the largest ethnic group in Akwa Ibom state. According to projected population of 2015 by the Ministry of Economic Development Uyo, Akwa Ibom State, NsitAtai has a population of 99,164 , with 50,242 males and
48,922 females. Okobo has a population of 138,828 ; made up of 70,790 males and 68,038 females. Uruan, has a population of 95,576 this is composed of 48,920 males and 46,656 females. Population of the study area was vital to the study because population is pivotal to the development of any region (Table 1 ).

\section{Sampling Procedures and Methods of Data Collection}

\section{Sampling procedures}

\begin{tabular}{|c|c|c|c|}
\hline Local Governments & Projected Population (2017) & Percentage Represented (\%) & $\begin{array}{l}\text { Villages Projected } \\
\text { Population (2017) }\end{array}$ \\
\hline \multirow{4}{*}{ Okobo } & \multirow{4}{*}{134,264} & \multirow{4}{*}{$35 \%$} & Egbghi Eta 1,848 \\
\hline & & & NungAtai 7, 232 \\
\hline & & & Ammong 20,534 \\
\hline & & & Total 29614 \\
\hline \multirow{5}{*}{ Uruan } & \multirow{5}{*}{153,101} & \multirow{5}{*}{$39.9 \%$} & EkpeneUkim 14,774 \\
\hline & & & IshietEkim 4,657.12 \\
\hline & & & NdonEbom 17,046 \\
\hline & & & Esukinwang 2,199 \\
\hline & & & Total 38676 \\
\hline \multirow{5}{*}{ NsitAtai } & \multirow{5}{*}{95,903} & \multirow{5}{*}{$25.02 \%$} & IkotInyang 948 \\
\hline & & & Idibia 21,299 \\
\hline & & & NdonEkpe 698 \\
\hline & & & Ikotmkpo 587w \\
\hline & & & Total $23,533.48$ \\
\hline Total & 383,268 & $99.9 \%$ & $91,822.92$ \\
\hline
\end{tabular}

Table 1: Sample Population.

Source: 2017 Population projected from 2006 National population census (NPC, 2006) [8].

\section{Sample Size}

The Taro Yamane Formula was used

$$
\begin{aligned}
& \mathbf{n}=\frac{\mathbf{N}}{1+\mathrm{N}(\mathrm{e}) 2} \\
& \mathbf{n}=\frac{91,822.92}{1+91,822.92(0.05) 2} \\
& \mathbf{n}=\frac{91,822.92}{1+91,822.92(0.0025)} \\
& \mathbf{n}=\frac{91,822.92}{959.17}
\end{aligned}
$$$$
\mathrm{n}=399.6 \approx 400
$$

Based on this a total of 400 respondents was the sample size. Table 2 shows the percentage of questionnaire administration (Table 2).

\begin{tabular}{|c|c|c|}
\hline LGA & Percentage (\%) & Sample Size \\
\hline Okobo & 32.25 & 129 \\
\hline Uruan & 42.11 & 168 \\
\hline NsitAtai & 25.6 & 103 \\
\hline TOTAL & 100 & 400 \\
\hline
\end{tabular}

Table 2: Questionnaire Administration.

In administrating the questionnaire, quota system was used. The LGA's were given questionnaires based on their percentage contribution to the total population. Okobo was given $32.25 \%$ (129) of the questionnaires, Uruan was given $42.11 \%$ (168) and Nsit Atai was given $25.6 \%$ (103) of the questionnaires respectively. A systematic sampling technique was employed in selecting households to be sampled. 


\section{Journal of Ecology \& Natural Resources}

\begin{tabular}{|c|c|}
\hline Community of residence & Number of respondents \\
\hline Amammong & 88 \\
\hline EbighiEtai & 9 \\
\hline EkpeneUkim & 64 \\
\hline EsukInwang & 7 \\
\hline Idiabia & 90 \\
\hline IkotInyang & 4 \\
\hline Ikotmkpo & 4 \\
\hline Ishiet & 22 \\
\hline NdonEbom & 74 \\
\hline NdonEkpe & 4 \\
\hline NungAtai & 33 \\
\hline TOTAL & 400 \\
\hline
\end{tabular}

Table 3 presents the communities where the respondents were drawn. A five kilometres $(5 \mathrm{~km})$ buffer was drawn around the Ibom International airport and all the communities were listed according to buffers $(1 \mathrm{~km}$, $2 \mathrm{~km}, 3 \mathrm{~km}, 4 \mathrm{~km}, 5 \mathrm{~km}$ ). A buffer was used to delimit the study area to enable the research study the distance decay in the area of tourism. Ten percent of the communities were selected at random from each of the buffer levels. Ten percent is the minimum level for any sample to considered valid [9]. The buffer map is presented in Figure 2.

Table 3: Community Residence of Respondents.

Source: Field data (2017).

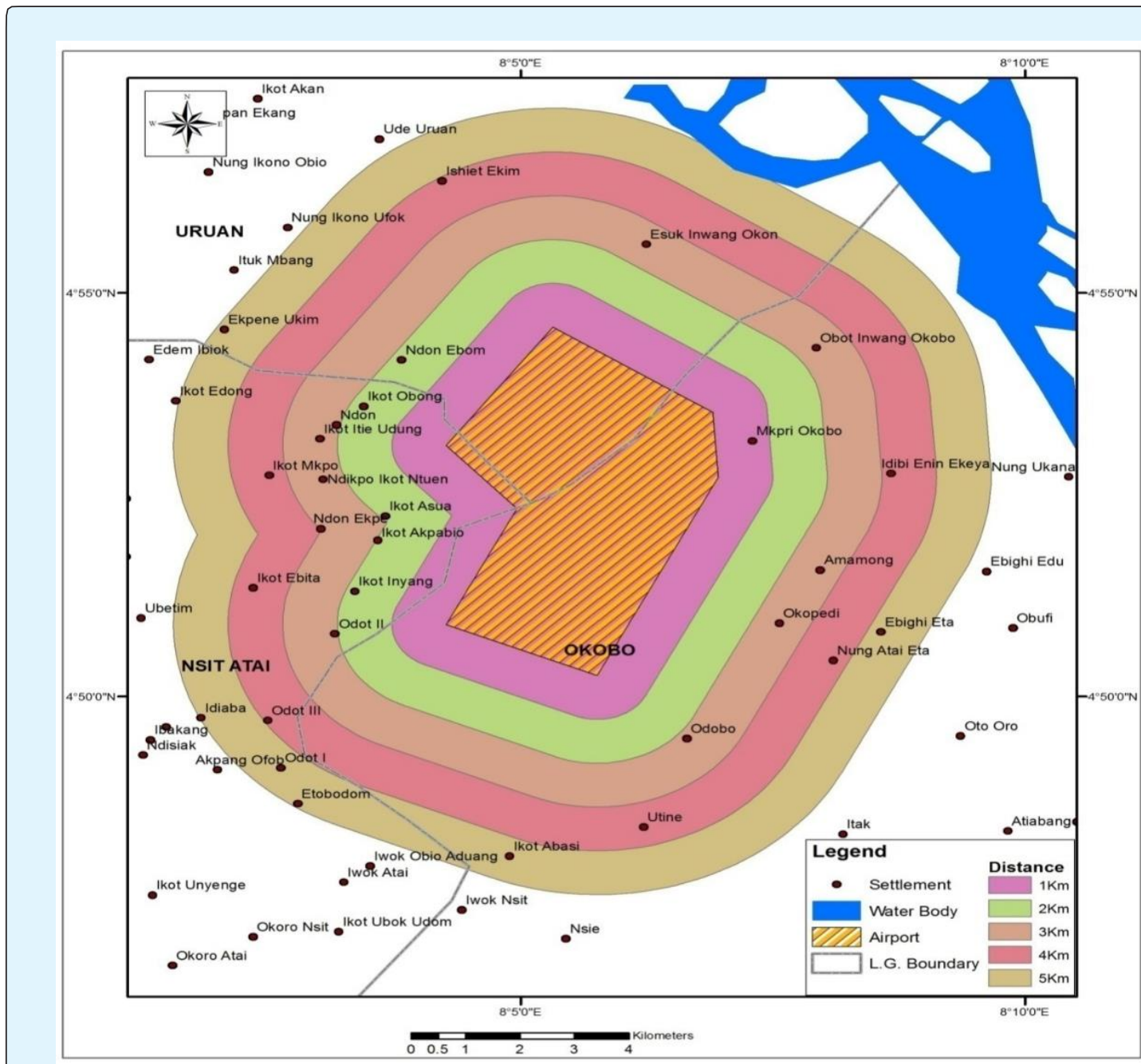

Figure 2: Buffer Map of Communities 5km from the Airport 


\section{Method of Data Collection}

The following variables were sought for socioeconomic information using structured questionnaires; socio-demographic information and tourism (Table 4).

\section{Socio-demographic information}

\begin{tabular}{|c|c|}
\hline Variable & Method of Data Collection \\
\hline Gender & Structured Questionnaire \\
\hline Marital status & Structured Questionnaire \\
\hline Levels of education & Structured Questionnaire \\
\hline Religion & Structured Questionnaire \\
\hline Community & Structured Questionnaire \\
\hline Employment Status & Structured Questionnaire \\
\hline Family Size & Structured Questionnaire \\
\hline
\end{tabular}

\section{Tourism}

\begin{tabular}{|c|c|c|}
\hline Variable & Indicators & $\begin{array}{c}\text { Method of Data } \\
\text { Collection }\end{array}$ \\
\hline Tourism & $\begin{array}{c}\text { Numbers of visitors Numbers } \\
\text { of tourism related business } \\
\text { which includes } \text { hotels, car } \\
\text { rentals, entertainment, } \\
\text { recreation). }\end{array}$ & $\begin{array}{c}\text { Survey } \\
\text { questionnaires }\end{array}$ \\
\hline
\end{tabular}

Table 4: Data set and method of collection.

\section{Method of Data Analysis}

Descriptive and inferential statistics were the major method of analysis used. Percentages and charts and maps were used to describe the extent of influence the airport has on local tourism of the airport host communities. Data collected on each of the variables were mapped to indicate their strength with distance.

\section{Result}

\section{Determinant of Airport on Tourism}

The study tried to assess the influence of the Obong Victor Attah International Airport on tourism using influx of visitors and changes in tourism related businesses related as major indicators. The following charts and tables represent the findings from the study (Table 5).

\begin{tabular}{|c|c|}
\hline Communities & Influx of Visitors \\
\hline Ndon Ebom & 70 \\
\hline Ekpene Ukim & 56 \\
\hline Ishiet Ekim & 22 \\
\hline Esuk Inwang & 0 \\
\hline Ammamong & 55 \\
\hline Nung Atai & 13 \\
\hline Ebighi-Eta & 7 \\
\hline Ikot Inyang & 2 \\
\hline Idiabia & 38 \\
\hline Ikot Mkpo & 2 \\
\hline Ndon Ekpe & 2 \\
\hline
\end{tabular}

Table 5: Influx of Visitors.

Source: Field Data (2017)

Table 5 shows the numbers of respondents from the communities who opined that the Obong Victor Attah International Airport has influenced the influx of visitors in the communities.

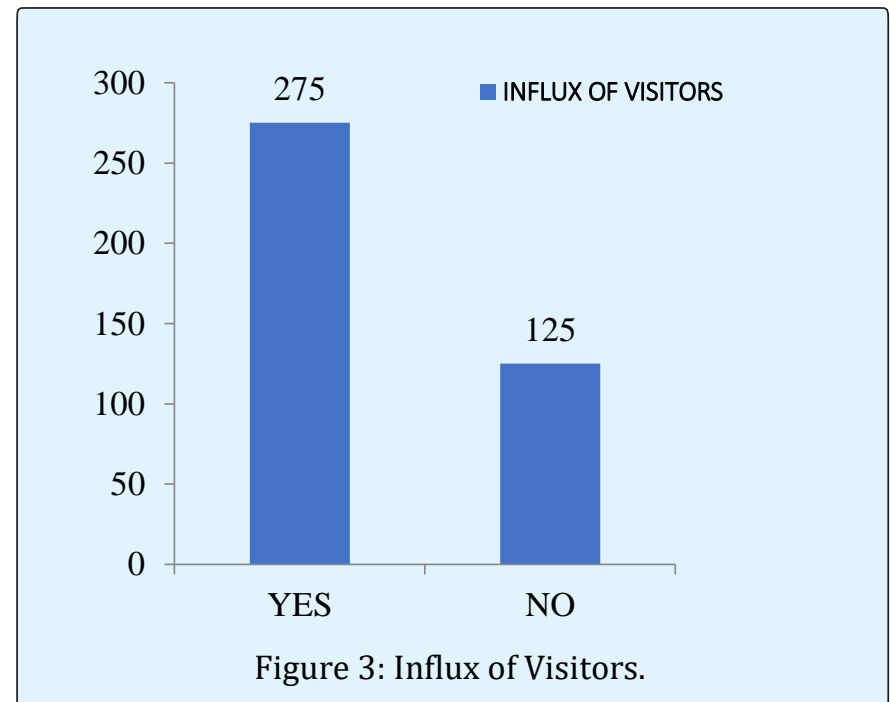

Figure 3 displays the Influence of the Obong Victor Attah International Airport on the influx of visitors. It showed that one of the major Influences of the Obong Victor Attah International Airport on tourism is the influx of visitors (275 respondents, 68.8 percent). Other respondents $(125 ; 31.3$ percent) were of the opinion that the airport had not caused any variation in the influx of visitors. The difference in response may be attributed to the fact that some people do not stay so close to the airport and may not observe certain events [10].

Figure 4 shows that influx of visitors as a result of the Airport is not a factor of distance. Contrary to the distance 
decay model, Respondents from Uruan L.G.A, who are of the opinion that influx of visitors are as a result of the Airport are almost evenly distributed across distances. In Okobo L.G.A, the positive influence and negative influence of tourism does not follow a regular pattern. The positive influence is more at $5 \mathrm{~km}$ distance and lowest at $4 \mathrm{~km}$. This is also so for Okobo L.G.A where positive and negative influence are highest at $4 \mathrm{~km}$ distance and lowest at $4 \mathrm{~km}$ distance respectively.

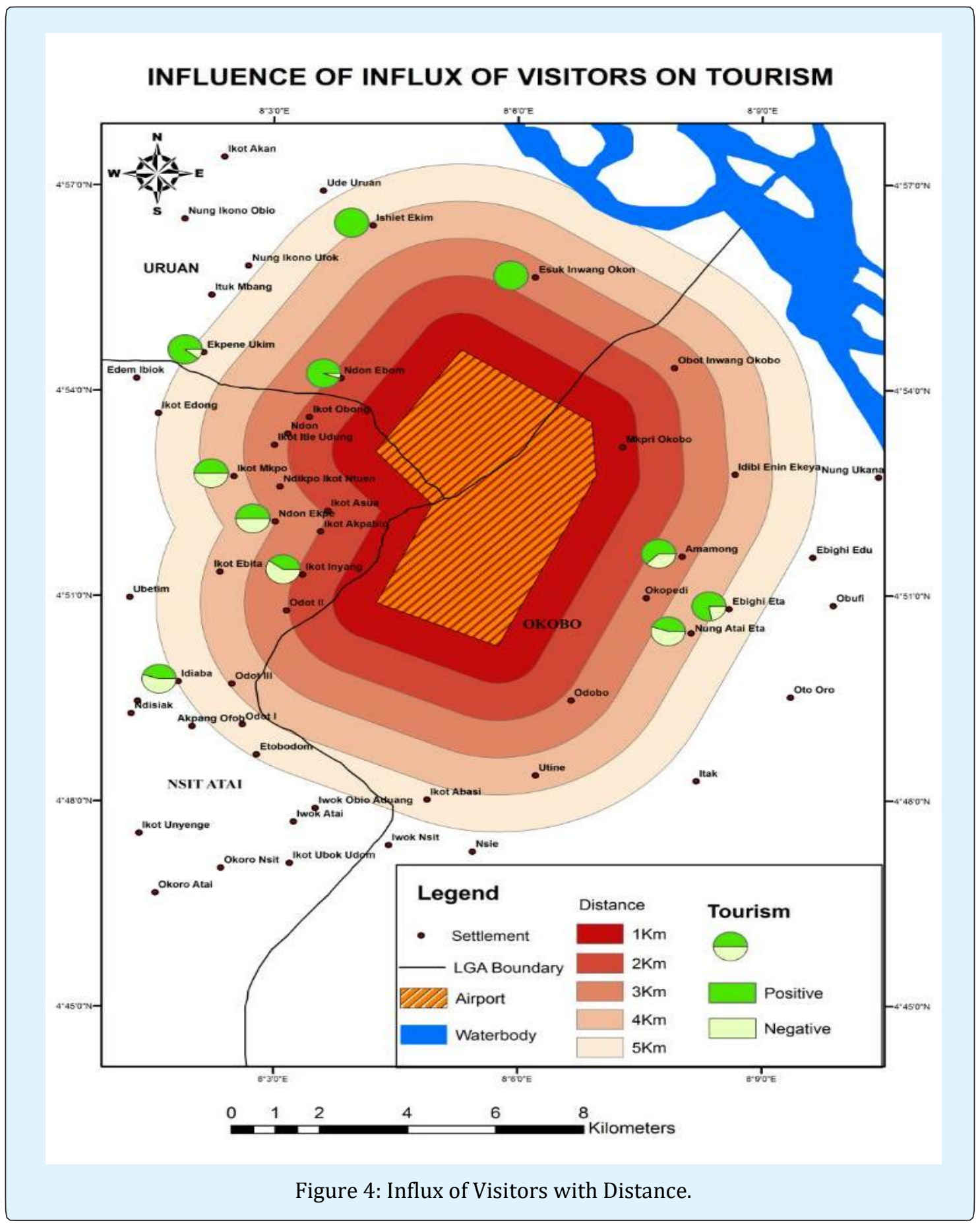


In the area of Influence of Ibom International Airport on tourism related businesses, 28 percent of the respondents were of the opinion that the Airport had led to the building of more hotels and motels, 115 (29 percent) increase in the production of souvenirs and souvenirs related businesses, 17 (4 percent) opration of car rental business $30 \quad$ ( 8 percent) increase in recreational businesses and activities, 5 ( 1 percent) had other view such as increase in educational activities. The odd thing was that 119 (30 percent) opined that the Airport did not influence any tourism related business. The difference in response may be attributed to the fact that some people do not stay so close to the airport and may not observe certain events (Figure 5) shows this distribution.

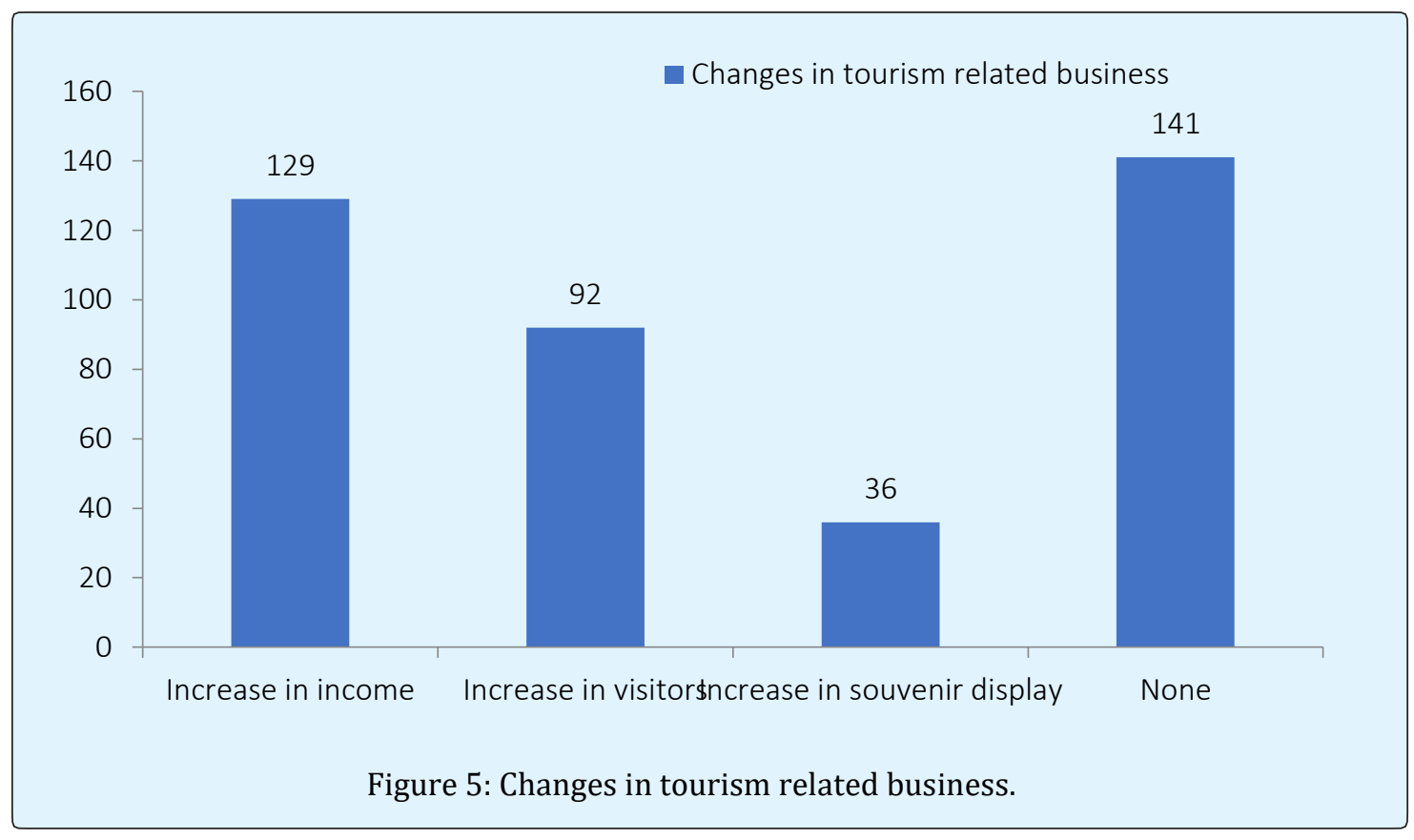

Figure 5 displays the influence of the Airport on the changes in tourism related businesses in the study area. It showed that the areas of major changes in tourism related businesses include increase in income (129 respondents, 32 percent), increase in visitors (92 respondents, 23 percent), increase in souvenirs display (36 respondents, 9 percent). Other respondents $(141 ; 36$ percent) were of the opinion that the location of the airport does not lead to any changes in tourism related business. The difference in response may be attributed to the fact that some people do not stay so close to the Airport and may not observe certain events.

\section{Test of Hypothesis}

A certainty in the study was needed to affirm if Obong Victor Attah International Airport contributed significantly to tourism of the selected host communities. Hence this hypothesis was tested.

$\mathrm{H}_{\mathrm{o}}=$ Airport does not significantly impact tourism

\begin{tabular}{|c|c|c|c|c|c|c|c|}
\hline Indicator & $\mathbf{R}$ & $\mathbf{R}^{\mathbf{2}}$ & $\mathbf{A D J ~ R}^{\mathbf{2}}$ & $\begin{array}{c}\text { STD } \\
\text { ERR }\end{array}$ & SIG & $\mathbf{B}$ & $\mathbf{F}$ \\
\hline Tourism & .061 & 0.004 & -.107 & 27.310 & 0.858 & .061 & .034 \\
\hline
\end{tabular}

Table 6: Summary of Simple Linear Regression Analysis of the Influence of the Obong Victor Attah International Airport on Tourism.

\section{Analysis by Author (2017)}

Information on the relationship between Airport and tourism were subjected to simple linear regression using SPSS version 20 . The results indicated that the $\mathrm{R}$ which was the correlation between the observed (Airport) and predicted dependent variables (Tourism) was low for tourism $(6.1 \%)$ and the R-Square or coefficient of determination indicated that the Airport contributed poorly to tourism (4\%). The magnitude and influence of these variables are shown by the B values. The positive B values for tourism shows a positive contribution of the Airport. The proportion of variance in the dependent variable (tourism) which was explained by the independent variable (Airport as represented by the distances from the Airport) is $-10.7 \%$. Based on the low 
(weak) correlation indicated by the $\mathrm{R}$ coefficient for tourism, it was concluded that Obong Victor Attah International Airport was not a major determinant of tourism in the host communities (Uruan, Okobo and NsitAtai LGA's of Akwa Ibom State).

\section{Discussion}

The study showed that one of the major Influences of the Obong Victor Attah International Airport on tourism is the influx of visitors (275 respondents, 68.8 percent). Other respondents $(125 ; 31.3$ percent $)$ were of the opinion that the airport had not caused any variation in the influx of visitors. The difference in response may be attributed to the fact that some people do not stay so close to the airport and may not observe certain events. This result is supported by the work of Costa (2014) [2] in a study of Regional Portuguese Airports, Local economy and Tourism development which showed that approximately 869,000 tourists arrived in the north through Oporto Airports. The area recorded 2.4 million tourists in 2010 and 3 million in 2012.

The study also revealed that in the area of Influence of Obong Victor Attah International Airport on tourism related businesses, 28 percent of the respondents were of the opinion that the airport had led to the building of more hotels and motels, 115 (29 percent) increase in the production of souvenirs and souvenirs related businesses, 17 (4 percent) operation of car rental business 30 (8 percent) increase in recreational businesses and activities, 5 (1 percent) had other view such as increase in educational activities and 119 (30 percent) opined that the airport did not influence any tourism related business. This is in line with Basnet (2015) [3] who studied air transportation impact upon the tourism industry of Nepal; Tribliuvan International Airport was used as a case study. It was observed that the airport contributed to tourism and tourism related businesses in the study area.

\section{Conclusion}

Conclusively, the importance of tourism to economic growth, national development, and poverty reduction cannot be overemphasized. This had been enunciated in recent national and international policies, such as the Vision 2020, Sustainable Development Goals (SDGs), New Partnership for African Development (NEPAD), and National Poverty Eradication Programme (NAPEP), among others. The potential for this sector is clearly enormous for Africa particularly Nigeria, but a lot has to be done to cash-in the dividends of these policy reforms. However, one of the major influences of the Obong Victor
Attah International Airport on tourism is the influx of visitors (275 respondents, 68.8 percent). Other respondents $(125 ; 31.3$ percent) were of the opinion that the airport had not caused any variation in the influx of visitors. The difference in response may be attributed to the fact that some people do not stay so close to the Airport and may not observe certain events. Also, visitors choose to lodge in the city than in communities within the Airport. In the area of influence of Obong Victor Attah International Airport on tourism related businesses, the business most influenced is the production of souvenirs and souvenirs related business.

Furthermore, the study discovered that the basic influence of the Airport was the influx of visitors. The study also revealed that in the area of influence of Obong Victor Attah International Airport on tourism related businesses, the business most influenced was the production of souvenirs and souvenirs related business. However to achive sustainable development goals (SDGs) and vision 2020 in developing countries, a special challenge is to stimulate development processes at the local level. The fruits of development may reach more of the population than do the centralized scheme. Better adapted development projects and programmes are quick to endanger broader public support and cause less undesirable social displacement than a few large centralized projects.

\section{References}

1. Njoya ET (2013) Air Transport and Destination Performance A case study of three African countries. (Ethiopia, Kenya and South Africa). pp: 48017.

2. Costa VN (2014) Regional Portuguese Airports, Local economy and Tourism Development PhD thesis.

3. Basnet S (2015) Air transportation and its impact upon the tourism industry of Nepal between Airport Neighboring and City Residents: A case study Tribliuvan International Airport'. Bachelor's Thesis Centria University of Applied Sciences, Nepal. Shiraz E-Med J 17(12): 43497.

4. World Tourism Organization (WTO) (2005) Tourism Market Trends, WTO, Madrid, 2005 Edition.

5. Adindu IB, Raimi MO (2018) Obong Victor Attah International Airport and Its Contributions to the Income of the Host Communities in Akwa Ibom State, Nigeria. Int J Earth Sci Geol 1(1): 11-15. 


\section{Journal of Ecology \& Natural Resources}

6. World Tourism Organization (WTO) (2001) “Tourism Vision 2020" WTO, Madrid.

7. Jain H, Pan H, Xiong G, Lin X (2016) The Impact of Civil Airport Layout to Yunnan Local Tourism Industry. Transportation Research Procedia 25: 7791.
8. National Population Census-NCP (2006) Akwa Ibom State Population Census, National Population Census, Federal Republic of Nigeria.

9. Udofia E (2011) Applied Statistics with Multivariate Methods. Enugu: Immaculate Publishers, pp 357.

10. World Tourism Organization (WTO) (2001) Tourism Highlight: WTO, Madrid. 